\title{
メチルオレンジを滴定液とした二相イオン対滴定による錠剤, 散剤及び注射液中のマレイン酸クロルフェニラミンの定量
}

\author{
永 忍 夫 $^{\circledR *}$, 永井千英香 ${ }^{*}$, 長 嶋 泉 ${ }^{*}$, 小 池 久*
}

Two-phase photometric ion-pair titration of chlorpheniramine maleate in tablet, powder and injection form using methyl orange as the titrant

\author{
Shinobu Naga, Chieka NagaI, Izumi Nagashima and Hisashi KoIKE* \\ *Department of Instrumental Analysis, School of Health Sciences, Fujita Health University, \\ Toyoake-shi, Aichi 470-11
}

(Received 26 August 1996, Accepted 14 October 1996)

Chlorpheniramine maleate (CPM) in tablet (CPM-T), powder (CPM-P) and injection (CPM-I) forms according to The Japanese Pharmacopoeia Thirteenth Edition (JP-XIII) was determined by the two-phase photometric ion-pair titration (TPPIT) method using Methyl Orange (MO) as the titrant. Ten $\mathrm{ml}$ of a buffer solution $(\mathrm{pH} 5)$ and $40 \mathrm{ml}$ of dichloromethane (DCM) were added to a sample containing about $0.5 \mathrm{mg}$ CPM and titrate in a $1 \times 10^{-3} \mathrm{M}$ MO standard solution; the solution was then stirred for 2 minutes. After the solution was separated into two layers, the absorbance of the DCM layer was measured at $425 \mathrm{~nm}$. By repeating this operation, a titration curve was prepared and the titration end point was obtained. The amount of CPM was calculated, and compared with that determined by the JP-XIII method. No significant difference was found in the accuracy between the two methods. Therefore, the TPPIT method is a useful method for the determination of CPM.

Keywords : two-phase photometric ion-pair titration; chlorpheniramine maleate determination; methyl orange.

\section{1 緒 言}

マレイン酸クロルフェニラミン（GPM）は抗ヒス夕 ミン薬の中では最も強い作用を持ちながら，副作用が非 常に少ないため種々のアレルギー疾患に広く用いられて いる.この医楽品の定量法は既に数多く報告されてい

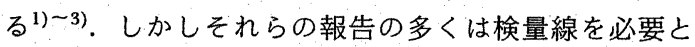
する比色分析法である. 第十三改正日本楽局方 (JPXIII) では，その製剤原料は過塩素酸による非水滴定

* 藤田保健衛生大学衛生学部機器分析化学教室: 470-11 愛知県豊明市沓掛町田楽ヶ䆶 1-98
法で定量されるが, 滴定終点の判別が難しいことが指摘 されている. 又, 錠剤, 散剤及び注射液は, その配合量 が極めて少なく, 紫外吸収スペクトル測定法により定量 するには, 賦形剤中の妨害成分の影響を除く必要があ る.そのために，まず酸性でエーテル抽出してエーテル 可溶物を除き, 次いでアルカリ性で遊離のクロルフェニ ラミンをエーテル抽出し, 更にこれを酸性で水相に抽出 して紫外部 $(265 \mathrm{~nm})$ における吸光度を測定し, 定量 されている4). 定量分析で, このような前処理を行うこ とはあまり好ましいことではない。そこで著者らはJPXIII で行われるような前処理を全く行わずに錠剤, 散 
剤あるいは注射液をそのまま武料として用い，CPM を 定量することができないかと考えた．

著者らはその目的のために, Mohammed らにより Two-phase photometric ion-pair titration (TPPIT) 法と 名付けられた方法 ${ }^{5)}$ 利用することにした。この方法 は, 試料も滴定液も共に有機溶媒には溶けず, 両者がイ オン対化合物を生成すると有機溶媒に溶ける場合, 試料 水溶液に有機溶媒を加えておき，滴定液を少量ずつ滴加 し，その都度有機相の吸光度を測定する．水溶液中に試 料が存在している間は，イオン対化合物が生成して有機 相の吸光度は徐々に高くなるが, 試料が反応してしまう とその吸光度は一定となる，そこで, 滴定曲線を作成し て，反応の終末点を見いだす方法である．著者らは，入 手しやすく, 精製が容易で, 可視領域に比較的大きなモ ル吸光係数を持つメチルオレンジ $(\mathrm{MO})$ を滴定液とし て用いることにし，JP-XIII に準拠した錠剤, 散剤及 び注射液を試料として, 前処理を全く行わずに GPM の 定量を試みた。

\section{2 実 験}

\section{$2 \cdot 1$ 試 薬}

MO 標準液: 和光純薬製試薬特級を, 一定の吸光係 数が得られるまで繰り返し水から再結晶した. その元素 分析の結果は, 計算值 $\left(\mathrm{C}_{14} \mathrm{H}_{14} \mathrm{~N}_{3} \mathrm{O}_{3} \mathrm{SNa} \cdot 1 / 2 \mathrm{H}_{2} \mathrm{O}\right)$ : $\mathrm{C}, 49.99 ; \mathrm{H}, 4.50 ; \mathrm{N}, 12.50$, 実験值: C, $49.94 ; \mathrm{H}$, $4.53 ; \mathrm{N}, 12.44$ であった.この MOをおよそ $1 \times 10^{-3}$ Mになるように蒸留水に溶加, モル吸光係数の值 $(\log \varepsilon=4.65 ; 0.1 \mathrm{M} \mathrm{HCl} ; 507.4 \mathrm{~nm})$ から正確なモ儿濃 度を求めて用いた。

CPM 溶液: 東京化成製試薬特級を $2 \times 10^{-3} \mathrm{M}$ にな るように水に溶かした。この溶液を必要に応じて希釈 し, 抽出溶媒の選択, 抽出 $\mathrm{pH}$ の検討及び抽出種の組 成の検討に用いた。

局方 CPM 注射液 (CPM-I) : A 社製注射液アンプル (CPM の含有量: $5 \mathrm{mg} / \mathrm{ml}$ ) 10 本を開封して混ぜ合わ せ, そこから正確に $5 \mathrm{ml}$ 採り, 蒸留水を加えて正確に $25 \mathrm{ml}$ とし, 試料とした.

局方 CPM 散 (CPM-P)：B 社製散剤（GPM の含有 量: $10 \mathrm{mg} / \mathrm{g}$ )をそのまま用いた.

局方 GPM 錠 $(\mathrm{CPM}-\mathrm{T}): \mathrm{C}$ 社製錠剂（GPM の含有 量: $2 \mathrm{mg}$ /錠) 20 錠をガラス製乳鉢で微細な粉末とし, 試料とした.

$\mathrm{pH}$ 緩衝液: Elving らの報告6) に従ってイオン強度 0.5 の緩衝液を調製して用いた.

抽出用の溶媒は，すべて蒸留水を飽和させたものを用
いた。

そのほかの試薬は市販の試薬特級をそのまま用いた.

\section{$2 \cdot 2$ 装 置}

TPPIT 法には日立製 100-50 型分光光度計に日立製 200-0525 型ミクロフローセル（セル容量 $0.5 \mathrm{ml}$ ) を装 着して用いた. 又, $\mathrm{MO}$ の純度の確認と標定には島津 製 UV-260 型分光光度計を使用した。 $\mathrm{pH}$ の測定には

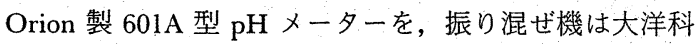
学工業製 SR-IIw 型を使用した。定量操作でのかき混 ぜには東洋製 MS-16B 型磁気かき混ぜ機を用いた。

\section{$2 \cdot 3$ 定量操作法}

局方試験 (JP 法): 注射液, 散剂及び錠剤はいずれも $\mathrm{CPM}$ をおよそ $3 \mathrm{mg}$ 含むように正確に採り, JP-XIII の定量法に従って操作した.

TPPIT 法: 注射液, 散剤及び錠剤はいずれも CPM をおよそ $0.5 \mathrm{mg}$ 含むように正確に採り, 滴定容器に入 れる. 緩衝液 ( $\mathrm{pH}$ 5) $10 \mathrm{ml}$ ，ジクロロメタン (DCM) $40 \mathrm{ml}$ を加え, 一定量の $\mathrm{MO}$ 標準液を滴加する. 滴加 後 2 分間磁気かき混ぜ機でかき混ぜる. 静置後二相に 分離したら, DCM 相をフローセルに吸い込み $425 \mathrm{~nm}$ における吸光度を読み取る. 吸光度を読み取った後, セ ル中の DGM 相を滴定容器に戻し, 再び MOを一定量 滴加, かき混ぜ, 吸光度値の読み取りを必要回数繰り返 す.なお, 滴定容器は気抜き穴として内径 $1 \mathrm{~mm}$ のテ フロンチューブを差し込んだシリコンゴム栓で密閉し， 溶媒の蒸発が最小限となるようにした。

\section{3 結果と考察}

\section{$3 \cdot 1$ 抽出溶媒と $\mathrm{pH}$ の検討}

$\mathrm{CPM}$ と MO のイオン対化合物を抽出するのに最も 適した溶媒と $\mathrm{pH}$ を検討した. 内容量 $100 \mathrm{ml}$ のスキー ブ型分液漏斗に $1 \times 10^{-4} . \mathrm{M} \mathrm{CPM}$ 溶液 $5 \mathrm{ml}, 1 \times 10^{-3}$ M MO 溶液 $5 \mathrm{ml}$, 緩衝液 $10 \mathrm{ml}$ 及び有機溶媒 $40 \mathrm{ml}$ を 採り, 振り混ぜ機で 5 分間振り混ぜた. 静置後有機相 を沃紙で沃過して溶媒中の水滴を除き, 吸収スペクトル を測定した. DCM, ジクロロエタン, クロロホルム, 4-メチル-2-ペンタノン, トルエン, ベンゼン, 四塩化炭 素について $\mathrm{pH} \mathrm{2 \sim 8}$ の範囲で検討した結果, $\mathrm{pH} 5$ 付近 で溶媒に DCM を用いた場合の吸光度值が最も高く, 二相に分離するまでの時間が最も短かった(およそ1 分間の放置で分離した). 従って, 本実験では抽出 $\mathrm{pH}$ を 5 とし，抽出溶媒には DCM を用いることにした。 


\section{$3 \cdot 2$ かき混ぜ時間の検討}

$\mathrm{CPM}$ 亡 MO のイオン対化合物を抽出するために必 要なかき混ぜ時間の検討を行った，滴定容器に $1 \times 10^{-3}$. M CPM 溶液 $1 \mathrm{ml}$, 緩衝液 $(\mathrm{pH}$ 5) $10 \mathrm{ml}, \mathrm{DCM} 40 \mathrm{ml}$ 及び $1 \times 10^{-3} \mathrm{M} \mathrm{MO}$ 溶液 $1 \mathrm{ml}$ を入れた. そして 0.5 , $1,1.5,2 ， 3 ， 4 ， 5$ 分間かき混ぜた後, 静置してその DCM 相の吸光度を測定した. その結果, 1 分以上のか き混ぜでその吸光度は一定の值を示した。従って定量操 作でのかき混ぜ時間を 2 分間とした。

\section{$3 \cdot 3$ 抽出種の組成の検討}

抽出される CPM とMO のイオン対化合物の組成比 を連続変化法により検討した。 内容量 $100 \mathrm{ml}$ のスキー ブ型分液漏斗に $1 \times 10^{-3} \mathrm{M} \mathrm{CPM}$ 溶液, $1 \times 10^{-3} \mathrm{M}$ MO 溶液, 緩衝液 $(\mathrm{pH} 5) .50 \mathrm{ml}$ 及び DGM $20 \mathrm{ml}$ を加 えて振り混ぜ機で 5 分間振り混ぜた。静置後, DCM 相 を沪紙で沪過して水滴を除き, 吸光度を波長 $425 \mathrm{~nm}$ で 測定した (対照は DCM を用いた)。 その結果, CPM とMOは 1:1のモル比で結合していることが分かっ た (Fig. 1).

\section{3・4 JP 法と TPPIT 法の比較}

JP-XIII に従って CPM-I, CPM-P, CPM-T につい てえれぞれ 5 回の測定を行い, その平均値と標準偏差 值を求めた. 又, TPPIT 法は, 2.3 の定量操作に従っ て操作し, 得られた吸光度值を滴加した $\mathrm{MO}$ 量に対し てプロットして滴定曲線を作成した（Fig. 2 に注射液 の滴定曲線を示す)．この曲線から作図法により MO 標 準液の消費量を求め, 試料 $1 \mathrm{~g}$ 又は $1 \mathrm{ml}$ 中に含まれる CPM 量を算出した. CPM-I, CPM-P, CPM-T につい てそれぞれ 5 回の測定を行い, その平均値と標準偏差 值を求めた.これらの結果を Table 1 に示す.

JP 法と TPPIT 法の精密度を F-検定により検討した. その結果 CPM-I, CPM-P, CPM-T いずれも 95\% 有 意水準で二方法間に有意の差は認められなかった. 次 に, $\mathrm{t}$-検定により二方法で得られた平均值の検定を行っ た。その結果, CPM-I については 95\% 有意水準で二 方法間に有意の差は認められなかった。しかし, CPM$\mathrm{P}$ と GPM-T については有意の差が認められた。 CPM$\mathrm{P}$ と CPM-T のどちらもその平均值は, JP 法が TPPIT 法よりも低い值を示している.これは, JP 法で抽出や 沃過の操作の際に主剤の損失が生じたのか，あるいは TPPIT 法で主剤以外に含まれる安定剤などが, MO と イオン対化合物を生成して抽出されたのか，が原因であ ると考えられる.しかし, JP 法と TPPIT 法で得られ た結果は, すべて JP-XIII の含量規定に十分適合して

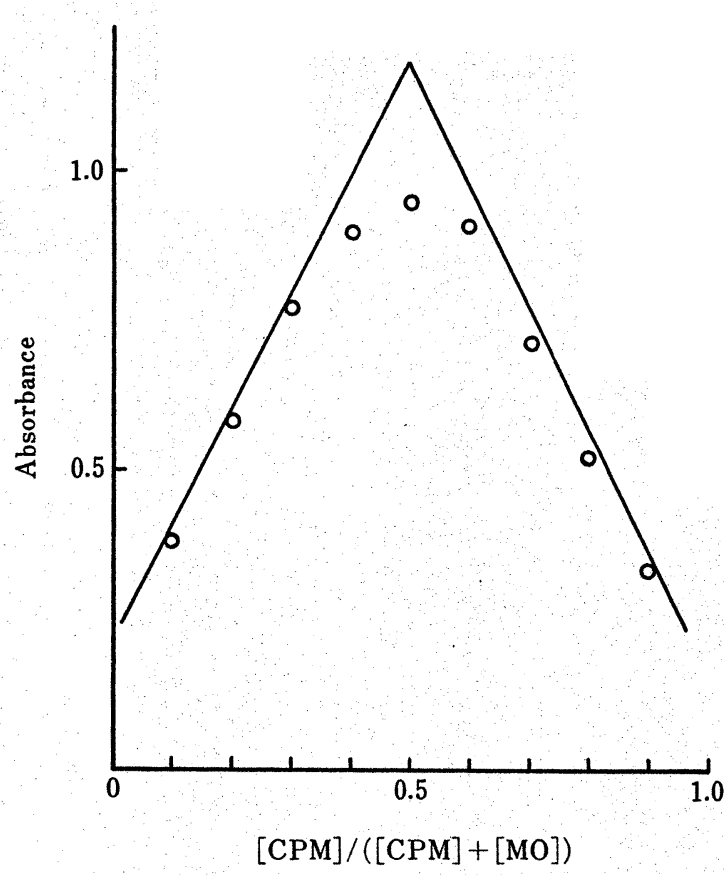

Fig. 1 Continuous variation method CPM-MO system

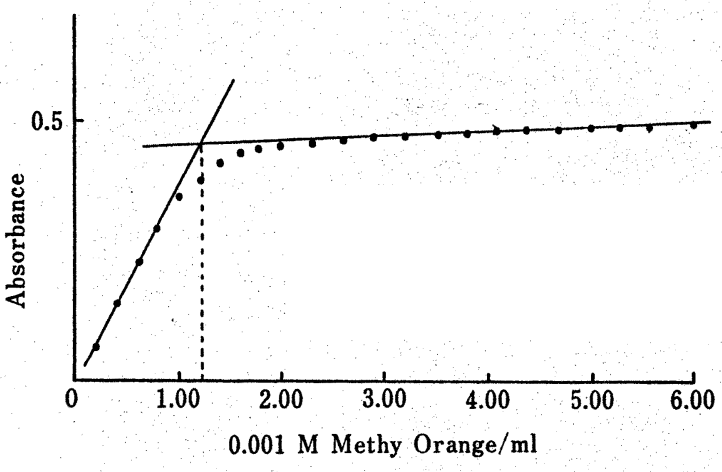

Fig. 2 Titration curve for the titration of CPM-I with $\mathrm{MO}$

Quantity of CPM: $5.018 \mathrm{mg} \mathrm{ml}^{-1}$; Concentration of MO : $1.068 \times 10^{-3} \mathrm{M}$

Table 1 Comparison of the TPPIT method with JP-XIII method

\begin{tabular}{|c|c|c|c|c|}
\hline \multirow[b]{2}{*}{ Sample } & \multicolumn{2}{|c|}{ JP-XIII method } & \multicolumn{2}{|c|}{ TPPIT method } \\
\hline & $\begin{array}{c}\text { Mean } / \mathrm{mg} \mathrm{g}^{-1} \\
\text { or } \mathrm{mg} \mathrm{ml}\end{array}$ & $\begin{array}{l}\mathrm{SD} / \mathrm{mg} \mathrm{g}^{-1} \\
\text { or } \mathrm{mg} \mathrm{ml}^{-1}\end{array}$ & $\begin{array}{c}\text { Mean } / \mathrm{mg} \mathrm{g}^{-1} \\
\text { or } \mathrm{mg} \mathrm{ml}^{-1}\end{array}$ & $\begin{array}{l}\mathrm{SD} / \mathrm{mg} \mathrm{g}^{-1} \\
\text { or } \mathrm{mg} \mathrm{ml}^{-1}\end{array}$ \\
\hline CPM-I & 5.016 & 0.012 & 5.026 & 0.021 \\
\hline CPM-P & 9.720 & 0.090 & 10.56 & 0.038 \\
\hline CPM-T & 19.50 & 0.063 & 20.20 & 0.035 \\
\hline
\end{tabular}

Five measurements were done for each method. 
いる. 従って CPM-I， CPM-P, CPM-T の定量には, JP-XIII で行われるエーテル抽出, 沪過などの前処理 の操作を全く行わずに, 製剤を直接試料とし, 又より少 ない試料量で, 更には化学量論に基づいて定量できる TPPIT 法は有用な方法である.

\section{文献}

1) 佐藤和夫, 外岡弘道: 薬学雑誌, 87, 231 (1967).

2）大橋 芳, 松尾賢明, 川崎敦子, 小池 久: 分析
化学 (Bunseki Kagaku), 17, 843 (1968).

3）尾西良一, 森田泰輔, 川村邦夫: 薬学雑誌, 90 , 46 (1970).

4）第十三改正日本薬局方, (1996)，(廣川書店).

5) H. Y. Mohammed, F. F. Cantwell: Anal. Chem., 52, 553 (1980).

6) P. J. Elving, J. M. Markowitz, I. Rosenthal: Anal. Chem., 28, 1179 (1956). 